\title{
Migration — Ecumenism — Integration
}

\begin{abstract}
The three concepts of migration - ecumenism - integration are rich in meaning. What is important is their order, the hierarchy of their occurrence. Migration is more or less any movement of people, individuals or whole groups. Ecumenism is in turn an appeal and an action. Its mission/task is to recognize in a certain group of people a religious difference and to make an effort to place it in an integral whole with other people who believe a little differently, but in the same God. Integration has the task of restoring or building an integral whole from people living in a particular territory.

Full integration is called individual or collective identity. Since migration violates to a greater or lesser extent - the individual or collective identity of both the country that receives immigrants and the immigrants themselves, integration aims to rebuild it, but no longer within the same mental structures, but rather ones enriched with new impulses that are the contribution of immigrants. The foundation - in our context, it is about faith in the God of Jesus Christ - remains unchanged, yet the superstructure undergoes some changes.
\end{abstract}

Keywords: migration, ecumenism, integration, faith, pilgrimage, freedom, Church

I am not a political scientist or sociologist. Nor am I a historian of ideas or someone who can predict the future or reach into it further than others. Not in the least. I graduated in the field of theological and philosophical anthropology, and in this area I publish. A few thoughts on migration - ecumenism - integration are the fruit of theological and philosophical reflections, personally very dear to me. Of course, my considerations do not pose to be exhaustive in any way. They are not comprehensive, either. I was only asked for a few comments on these extremely important issues. 
It is strange, if not alarming, that in the context of the mass phenomenon of migration today the discussion about it seems rather feeble. There is a lot of talk about accepting or not accepting migrants, and there is little substantive debate about this phenomenon, which is very common nowadays. I am therefore glad that such a debate is taking place right now. Therefore, I will come back to the topic of my article.

We have three concepts, each very rich in meaning. I believe it is very important that they are arranged in order, like a hierarchical sequence. Their horizontal arrangement seems to take into account the sequencing of the phenomena we are interested in at the moment better, more clearly. In the first place, we are dealing with migration, more or less free movement of people, individuals or whole groups, followed by ecumenism, which is both an appeal and an action. Its important mission/task is to recognize in a particular group of people a religious difference and to make an effort to incorporate it into an integral whole with other people who believe a little differently, but in the same God. Integration, which is the third stage of action here, has the task of restoring or building an integral whole from people living in a particular territory.

The vertical view, in turn, allow to us to build from the above three concepts a kind of pyramid. The top would then be ecumenism, while at its base - migration and integration. For if both, that is to say, migration and integration, are primarily the work of human effort, which changes its place of residence and integrates (or not) with the new environment to which it has come, then ecumenism, as theology teaches, is rather a divine/human work, not only human, but also God's. Theology takes the view that an authentic ecumenical dialogue is not only born out of the will of people, but also out of the impulse of the Holy Spirit. He is its initiator, animator and guide. The Decree on Ecumenism of the Second Vatican Council teaches:

What has revealed the love of God among us is that the Father has sent into the world His only-begotten Son, so that, being made man, He might by His redemption give new life to the entire human race and unify it. Before offering Himself up as a spotless victim upon the altar, Christ prayed to His Father for all who believe in Him: "that they all may be one; even as thou, Father, art in me, and I in thee, that they also may be one in us, so that the world may believe that thou has sent me." In His Church $\mathrm{He}$ instituted the wonderful sacrament of the Eucharist by which the unity of His Church is both signified and made a reality. He gave His followers a new commandment to love one another, and promised the Spirit, their Advocate, who, as Lord and life-giver, should remain with them forever. ${ }^{1}$

1 Vatican Council II: Decree on Ecumenism “Unitatis redintegratio" [21.11.1964], no. 2 . 
In the context of what I have already said, it is now necessary to take a closer look at each of the three concepts/realities. I intend to show the specificity of each and every one of them in order to then point out their intrinsic substantive connection and the need for harmonious cooperation in order to realize a new quality and a new integral unity, enriched by new values, so far unknown or poorly exposed.

\section{Migration}

What is migration? ${ }^{2}$ What attitude does the Church have towards it? What kind of threats and opportunities does it bring? Where to look for its strong aspects and where does it hide its weaknesses?

Migration is commonly defined as a permanent or temporary change of place of residence related to crossing administrative borders, for instance, state or city. Migration is an ambiguous concept. Depending on the direction, internal migration is distinguished, for example, from a city to a village or from a village to a city, or from a city to a city or from a village to a village. The scope of internal migration also includes spiritual migration, when a person "moves" between different spiritualities, but without a visible change of religious affiliation. Such a person is internally (spiritually) dispersed, although externally he or she seems to be stable, continuing uninterruptedly in the existing religious community.

Yet another type of migration is external migration, which leads to a change of country of residence. Then we refer to emigration or immigration, repatriation or deportation. We also distinguish migration based on its reason. In this situation, we refer to economic migration or political migration. Apart from them there is also religious migration, to avoid religious persecution or because of religious disputes. This type of migration includes family migrations, the aim of which is to bring families together, to conclude marriages between people from different countries. Tourist migration is also included in this type of migration. On the other hand, due to the duration of migration, we distinguish permanent migration or temporary migration, for instance, a trip to another country for work or travel for tourism.

${ }^{2}$ See the extensive study on migration: Wokót problematyki migracyjnej. Kultura przyjęcia. Eds. J. Balicki, M. Chamarczuk. Warszawa 2013. 
Migration does not seem to be close to human nature. I am even inclined to say that it is rather alien, unnatural. It is much closer to the world of birds, mammals, etc., which migrate from place to place, depending on the season and geographical area, to get food or survive the difficult seasons. Periodic movement is therefore natural, even necessary for them. Having no permanent place anywhere, they migrate to survive. They only live owing to regular migration.

The case of man (but also the case of women) is rather different, I would even say radically different. Psychologists say that a certain stability is closer to his nature, some kind of permanence, a strong need for rooting, a very strongly felt need to remain in a place, around a hearth, even necessary for the birth and upbringing of offspring. For this reason, migration, movement, wandering are alien to him by nature. He is only allowed to do so when he has to, by necessity, because of his personal needs or the needs of people close to him. If he decides to migrate, he (almost) only feels a certain threat or danger, whether physical, economic, spiritual, or religious. Sometimes he also emigrates in search of adventure, in escape from someone or something, but even then migration is not natural. When there is no such threat, when nothing threatens him, he is inclined to choose stability, staying in his place and systematic spiritual, intellectual or economic development. ${ }^{3}$

A careful reading of the history of development of great civilizations seems to confirm the foregoing assumptions. It shows that, in general - to use broad terms - the development of the human civilizations we know went from nomadism to stability, from the more or less free "movement" of groups of people to the permanent occupation of specific areas. An example of this is the story of Abram, who began his migration from Ur of the Chaldeans and headed for Palestine, the promised land for him, a hope for a better future, a place of permanent residence. His migration to the West, to Palestine, was a pilgrimage to a particular place, to a land "flowing with milk and honey," an area chosen for him by God himself. His and his family's migration was by no means a migration from place to place, a constant movement from place to place, a search for a place for a better future. On the contrary, it was going to the place God chose for him. There, because he believed God's promise, he expected to find the land of his dreams, land for himself and his people for all generations, forever.

The author of the Book of Deuteronomy reinforces our arguments. So when he speaks of the injunction to make a sacrifice to God of the first

${ }^{3}$ Of course, I am not addressing here the touristic and cognitive migration, after which a person returns to their original place. 
fruits of all the land, "which the Lord, your God, gives you," of the Deuteronomy writes that every member of the Family of Abraham was obliged to say the following words, as if a kind of credo, an identity formula:

My father was a wandering Aramean who went down to Egypt with a small household and lived there as an alien. But there he became a nation great [...]. And bringing us into this country, he gave us this land flowing with milk and honey. ${ }^{5}$

The Deuteronomy does not say here anything about migration. Nothing is said about wandering around or roaming around the wilderness, but rather of "leaving" one's land and "entering" a new one. This new land is therefore a gift from God, a land given as property, a country that is opulent and bountiful because given by good and mighty God.

The history of Abraham was not without significance for Christianity. He who followed God's voice faithfully became, at the same time, a model, a guide for generations of believers, for all Christianity. Although it accepts the phenomenon of migration, it is much closer to the idea of following Christ (sequela Christi), imitating Him (imitatio) or making a spiritual pilgrimage (peregrinatio) in His footsteps.

All these concepts assume a certain direction (of movement), a clear sense of purpose. It is following Christ towards a designated direction, that is, the goal of closer union with Him. This is also what the pastoral care of migrants serves. It has a double purpose: the first is negative, the second is positive. The negative comes down to making various efforts to prevent the spiritual or moral loss of migrants during their journey to their so-called promised land. In turn, the second, positive, goal is to bring them closer to God and His values, which allows them to feel "at home" in the place they come to.

How, in this context, should we understand human freedom of movement? Theology takes the view that "the freedom of man to wander from place to place belongs to his fundamental personal rights," a right, as I think and I will address, to some extent additional. The right to wander seems to be a derivative right from the right a human person wants to exercise, to be and to develop comprehensively (he/she and his/ her loved ones) where the human person is.

${ }^{4}$ Deut. 26, 1.

${ }^{5}$ Deut, 26, 5, 9.

${ }^{6}$ Z. GLAeSER: “'Swój’ i ‘obcy’ w perspektywie doktryny chrześcijańskiej.” In: „Swój” i „obcy” $w$ kontekście współczesnego kryzysu migracyjnego. Doświadczenia i zadania Kościołów i społeczeństwa. Eds. Z. Glaeser, G. Giemza. Warszawa 2017, p. 26. 
The Church ${ }^{7}$ teaches that man enjoys the fundamental right to migration in two ways. This means that he has both the possibility of leaving his own country, namely, the right to emigrate (emigrare), and the legal possibility of entering another country, a new geographical area (immigrare), in search of better living conditions. However, following the teachings of the Church, such as St Paul VI's Motu proprio "Migratorum Cura", it teaches that, although the right to free movement must be guaranteed to the person, it must not be forgotten that this right is derived from the primary and fundamental right, which is his inalienable right to achieve a life of dignity. This means that a fundamental right is to live in dignity, and it is only in its context that the right to emigrate or to reside permanently in a place that a person already is should be considered. First and foremost, a person has the right to have his/her own country and to develop comprehensively where he/she is, and only then, possibly, look for a new place that is favourable for better development.

There is a high price to be paid for the right to migrate. It is a social, spiritual, ethical, or moral price. Migration is not an idyll, but an extremely difficult and sad challenge. It is a challenge not only for the emigrant, the country he leaves and arrives in, but also for the ecclesial community which he departs and the one which welcomes him. This is extensively discussed in the Erga migrantes Instruction, published by the Pontifical Council for the Pastoral Care of Migrants and Itinerant People on 3rd of May 2004. Its authors believe that the phenomenon of mobility is a challenge for Christians. ${ }^{9}$ I will not dwell in detail on the difficult issues raised by this Instruction, but I will only say that it considers migration as a specific problem. In practice, this means that the migrant and the Church (though not only) have specific tasks to fulfil.

Where does the Church's caution towards migration come from? How to explain it? Why does the Church speak of it in terms of a "challenge," a "problem"? I think that the causes can be many and varied. We can assume that one of the most important causes concerns, paradoxically, the person who emigrates. The one who (under the influence of various factors) finally decides to leave his former place of residence must con-

${ }^{7}$ See e.g. John XXIII: Encyclical Letter "Mater et Magistra” [15.05.1961], no. 4; JoHn XXIII: Encyclical Letter "Pacem in Terris" [11.04.1963], no. 24; PAUL VI: Apostolic Letter "Octogesima Adveniens" [14.05.1971], no. 17.

${ }^{8}$ PAUL VI: Apostolic Letter in the Form of Motu Proprio "Pastoralis Migratorum Cura" [15.08.1969].

9 Pontifical Council for the Pastoral Care of Migrants and Itinerant PeoPLE: Instruction Erga Migrantes Caritas Christi (The Love of Christ Towards Migrants) [3.05.2004], no. 102, http://www.vatican.va/roman_curia/pontifical_councils/migrants/ documents/rc_pc_migrants_doc_20040514_erga-migrantes-caritas-christi_en.html [access 30.06.2020]. 
front the new reality which he ignored. Thus the one who is the Church's "path" is subjected to the changes that are caused by his entry into the new path. The Church's task, therefore, is to proclaim God to him, no matter where he is or what he does. It must strive to promote him, defend his integral development, the sustainability of his family relationships, love for children, etc. This task becomes particularly difficult for the Church in situations of migration. It very often undermines or takes away a person's original dignity, deprives him of the social status he enjoyed in his previous place of residence, weakens or destroys his personal, family, social or ecclesiastical life.

Even a brief look at the phenomenon of migration shows that it gives rise to some kind of "disintegration" of the unity that has existed so far (in the understanding of family, country, or something larger). Migration causes a certain "fluidity" of people, and thus also a "fluidity" of values. By its very nature, migration, which is a decentralist process, breaks down what was previously unified, permanent, somehow organically connected. The migrant leaves his current place of residence, his "home" and departs in search of a new one. The decentralist tendency, strongly connected with migration, can be taken seriously. But when I address the decentralist dynamic hidden in migration, I also want to mention a certain "destructive" aspect, a certain "destruction" of what is or was. It is a decomposition (more or less visible, depending on the number of emigrants) of existing social, cultural, or ecclesial structures. It is important to remember that it is not an anonymous person who emigrates, but a specific person, that is, a father, or a son, or a daughter, or a mother... The migration of an individual makes the rest of the family or clan remain "in place" and suffer.

Migration refers to very specific people: some migrate, while others related to them - stay (their families, friends, sick or suffering parents..., their former country that educated them, sought their full development, their health...). When an emigrant finally arrives in his country, in his he thinks - little "promised land," he is often faced with a difficult and long process of "integration" into the new environment. He pays a high price for this, sometimes even the price of his life. And yet, despite the potentially high price to be paid he, he emigrates. Thus, St. John Paul II said that migration, although it is an evil, is sometimes a necessary evil. ${ }^{10}$ In the same issue of his encyclical Laborem Exercens he wrote that:

Man has the right to leave his native land for various motives - and also the right to return - in order to seek better conditions of life in another

10 John Paul II: Encyclical Letter “Laborem Exercens” [14.09.1981], no. 23. 
country. This fact is certainly not without difficulties of various kinds. Above all it generally constitutes a loss for the country which is left behind. It is the departure of a person who is also a member of a great community united by history, tradition and culture; and that person must begin life in the midst of another society united by a different culture and very often by a different language. In this case, it is the loss of a subject of work, whose efforts of mind and body could contribute to the common good of his own country, but these efforts, this contribution, are instead offered to another society which in a sense has less right to them than the person's country of origin. ${ }^{11}$ [emphasis mine - ZJK]

If migration enriches the country that receives migrants, it impoverishes the one that they have left. It was poor and it becomes even poorer.

\section{Integration}

If we place "ecumenism" in the area of awareness of (the need to exist and have) common home, then integration comes first in the area of awareness and then in the area of action.

Similarly to migration, integration, which means "coming" to a new place, is not a completely unambiguous concept. It also has many different, but not always bright shades. For example, it is used in the area of economics, ${ }^{12}$ but also when talking about social life or personal integra-

${ }^{11}$ Ibidem.

${ }^{12}$ In the area of economics, for example, there are the concepts of horizontal and vertical integration. The former includes operational integration, which is served by technology and infrastructure, intellectual integration, which is based on knowledge, social integration, which is based on social bonds between employees, and emotional integration, which arises in the process of shaping identification with the organisation and its goals (M. Bugdol: Wartości organizacyjne: szkice z teorii organizacji i zarzadzania. Kraków 2006). Horizontal integration is assumed to: improve the company's financial situation, increase its creditworthiness, increase its market share, reduce the company's unit costs, improve profitability, achieve a better bargaining position in relation to suppliers and customers, reduce the instability of the company's environment and reduce threats to the organization from smaller market competitors. Vertical integration, on the other hand, consists in combining technologically separate phases of production, sales, distribution or other processes within a single company. This type of integration also has measurable benefits, such as access to technology, ensuring supply or demand, counteracting bargaining power and distortion of input costs, increasing the ability to differentiate, surpassing barriers to entry and mobility, entering a higher rate of profit or defending against being cut off from access to customers or suppliers by integrated competitors. 
tion. The latter area, related to personal integration, seems to be particularly important and up-to-date. It has been important for a long time, in fact, forever, but in our times, its validity is increasing greatly. Proper integration is in fact able to counteract the various degrees of depression, schizophrenia, and other disorders of the person, which are very often caused by a lack of internal integration.

In all cases, regardless of the area in which the term is used, when it comes to integration, it means a set of specific centripetal activities. Thus, integration is, in a way, on the opposite side of the barrier to migration, which is of a centrifugal nature. In short, integration merges what migration has broken down or what full integrity has questioned, what it has challenged. The main aim of integration is therefore to "rebuild" or "restore" or "give" a certain integrity that has been distorted by migration processes. Re-integration creates a new quality, generally better than it was before.

In the process of unification, which is what we are most interested in here, that is integration, various means are used. They are related to the realization of their goal, that is, integration. As a result of their usage, the unity is "restored" that was lacking before, or created a new: better and of a deeper kind. Integration has the task of harmonising the diversity of elements that were previously not fully (or not at all) harmonised, whether in legal, cultural, or ethical terms.

What is important in all of this is the aspect of "novelty" of the concept of integration, which is revealed in the course of its implementation. The new reality that emerges from integration is therefore no longer a mere "recreation" of a previously (formerly) existing unity. It is a new creation, of a new quality, previously perhaps alien or at least unknown. This new degree of integration (social, parish, local, state, etc.) uses in part the material of the old, that is to say, what it stands for, what already exists, what the local community lived, its system of values, its cultural and artistic heritage, etc., while at the same time introducing certain novelties, so far unknown, alien. These are novelties of both a substantive and methodical nature, which until now were lacking in a community experiencing the process of integration with a group of people who came from another cultural area. If, therefore, a group of people migrates and appears in a new area (geographical, spiritual, ecclesiastical or any other), its integration into the community there is never, in principle, reduced to a passive reception of all that comes up, what it encounters. In fact, it naturally introduces new elements which were previously alien to the local community. ${ }^{13}$ As a result of the harmonious interaction of

13 This was when Abraham entered the promised land or when the Germanic tribes crossed the borders of the Roman Empire. 
the group of people arriving and receiving them, a new identity is born, a new quality.

\section{Absolute need for integration}

The need for integration is growing as migration progresses. As one grows, so does the need to make efforts to integrate more quickly and fully. This means that all kinds of initiatives aimed at promoting or specifically implementing an ever deeper integration of people (arriving and present) should be intensified. They should also have sufficient resources to achieve their goal.

It should be noted immediately that in Europe and Poland, immigrants, apart from all other spiritual or cultural, political or religious aspects, are an economic and demographic necessity. It is forecasted that in 2050 immigration from outside the EU to European countries will reach about 40 million people in total. ${ }^{14}$ However, there is no shortage of those who believe that it will be much larger and may exceed these figures. But still, regardless of the inflow of immigrants, the overall number of native inhabitants of many European countries, including Poland, will decrease from year to year. The Polish society experiences labour shortages, which in turn has a negative impact on the economy and its development. Sociologists are sounding the alarm and claim that without the inflow of immigrants the rich countries of Europe are in danger of extinction. Alongside this, the systems of values developed by the Christian culture of Europe will also be forgotten.

Another sad issue is the progressive aging of the native inhabitants of our continent. According to the data of the Central Statistical Office, in the years 2002-2009 the number of people aged 60 and over increased from 6,486 thousand to 7,283 thousand. In 2010 there were 7,397 thousand of such people. Thus, the share of this age group in the total number of Polish inhabitants increased from $17.0 \%$ to $19.4 \% .^{15}$ Both the CSO and demographers have no doubt that the demographic situation of Poland is difficult and will not change quickly. Despite the recorded increases in births, the so-called birth depression persists. To put

${ }^{14}$ Anticipating Future Migration into Europe (2018-2050), aetusinpraesens.org/ docs10s/futmigrat.php [access 19.07.2021].

${ }^{15}$ See Rządowa Rada Ludnościowa: Sytuacja demograficzna Polski. Raport 20102011. Warszawa 2011, p. 133. 
it simply, the low birth rate does not guarantee simple replacement of generations. In order for this to happen, an average of 210-215 children per one hundred women (aged 15-49) should be born annually. In 2015 it was only 129. Polish citizens are getting older as a group, while immigrants, both in Poland and in Europe as a whole, are demographically young, $70 \%$ of whom are between 15 and 44 years old. They are therefore people that neither Poland nor Europe can do without. Bringing immigrants to equality is the basis for some exchange, which benefits both Polish citizens and immigrants. This is more beneficial for us than for them. Equality of rights, obligations and values is a profitable exchange. ${ }^{16}$

\section{Degrees of integration}

Properly understood integration is a living process, full of internal dynamics and changes. It is not a one-sided process; it does not concern only immigrants or those who receive them. On the contrary, it necessarily requires the involvement of both parties in order to be effective. The degree of their involvement may vary a little, but it must not be completely lacking. Integration must be mutual, involving the immigrant and the inhabitants of the country that has opened its borders to him/her equally.

Integration is not a fully self-contained process, nor is it completely automatic and unprompted. Proper integration also needs the right environment and the right tools. Only then can it expect optimum realization of its goals. It has to be guided, and it has to be guided wisely.

Sociologists, but also psychologists, believe that the "integration" activities undertaken by the various entities should apply the methodology of "growing closer together," that is, a specific effort of both sides, newcomers and hosts alike, in order to get to know each other better and create social bonds which do not exist yet. In order to achieve this "growing closer together," appropriate political actions, often called "multisectoral," are necessary. What are they about? There may be many examples of them, but it is worth mentioning, for example, the integration on the labour market and the fight against the formation of "ghettos." However, these are only some of the forms of this "multisectoral"

${ }^{16}$ See S. Gozi: “Kilka refleksji na temat: 'Imigracja i integracja'.” In: Migracja — wyzwanie XXI wieku. Ed. M.S. ZIĘBA. Lublin 2008, pp. 121-126. 
political action. It is also necessary to develop clear, explicit criteria to make it more possible for immigrants to participate in the integration of their new living environment. To this end, it is necessary to ensure a programme that allows immigrants to take co-responsibility for the fate of their host country (e.g. knowledge of the language, national history, literature, spiritual and cultural heritage...). This would be a longterm programme, but it is necessary for the integration to be authentic and deep. Furthermore, it is an absolute priority to have a deep awareness on the part of the hosts that they possess appropriately healthy and strong spiritual, ethical, aesthetic and other values with which to integrate newcomers, making them not only new citizens of their country, ${ }^{17}$ but also co-responsible for the further development of their native culture. When the host society lacks such values or when they are weak, disrespected or disregarded, such society is in danger of spiritual, cultural or religious extinction. Their former culture may slowly be marginalised by the culture of newcomers. This will also be the case when the culture of immigrants appears to be spiritually poorer in the initial phase.

The proper management of the whole process of achieving equality by immigrants in the new society, the wisdom of the hosts to share with them their participation not only in rights but also in duties and values, will be an important element in their full integration. Their presence will then indeed become something very beneficial to the society in which they are present. It will make the society richer in many, so far unknown, aspects.

The natural environment of integration is the very place where an immigrant lives, that is, countries, provinces, regional governments of various levels, parishes. The latter, the parish, is particularly important because it is "a real school of encounter with people of different religious beliefs and cultures." 18 Ecumenical activities are also part of this subject.

17 "If, during the period of application for citizenship, an immigrant lost his job, he could be considered a burden and rejected." S. GozI: Kilka refleksji na temat..., p. 123.

${ }^{18}$ John Paul II: Message for the 88th World Day of Migration 2002: "Migration and Inter-Religious Dialogue" [25.07.2001], no. 3. http://www.vatican.va/content/john-paul-ii/ en/messages/migration/documents/hf_jp-ii_mes_20011018_world-migration-day-2002. html [access 30.06.2020]. 


\section{Ecumenism as the "soul" of integration}

In this way we have reached the third part of our subject, that is ecumenism. ${ }^{19}$ It should be pointed out from the start that the term itself relates to a rich and multidimensional concept. Since it is both vertical and horizontal in nature, ecumenism has theoretical and practical tasks. On the one hand, it is characterised by a strong reference to God as the source and promoter of unity; on the other hand, it calls, or forms, mobilises members of the Christian Churches to cooperate with one another in achieving visible unity. The future visible unity (a kind of spiritual integration) is therefore the fruit of human efforts and God's grace.

Theology teaches that the ecumenical movement was born out of the experience of a living faith that did not accept division among Christians because such division contradicts lie the great desire of Christ's followers to love one another, and constitute visible unity. The ecumenical movement therefore reminded us that all Christians, and even more, all men and women (including those who do not know or accept this knowledge), are sons and daughters of Jesus Christ; for all of them He gave His life and for all of them He is now Lord and Teacher. He reminded us that it is the task of Christians to give visible and clear testimony of God's presence in the world and of His love.

Theology teaches that living faith does not accept any division into better or worse. It is therefore easy to agree that by its very nature ecumenism has an integrative dimension, since its task is to integrate believers, so far divided and dispersed, into one visible Church of Jesus Christ. The integrating force here is a lively and strong faith in Christ, while all the rest (i.e. dialogue, undertaking work together, education, etc.) is purely an instrument.

The ecumenical movement therefore has an important role in the integration process. This role does not only refer to the integration of believers in Christ, but indirectly also to the integration of people from other cultures and other beliefs. Its task is to introduce them into the area of Christian values. This cannot be done by one Christian community alone, by the Roman Catholic Church or by some evangelical community. It is the task of every faithful Christian, every religious community. In the growing phenomenon of migration, it is essential that all Christians act together. The cooperation of Christians in this field can also be an element stimu-

${ }^{19}$ I have written a lot about ecumenism, but I want to draw attention to one of my publications: Z. J. KiJAs: Odpowiedzi na 101 pytań o ekumenizm. Kraków 2004. 
lating greater intimacy between them, a deeper experience of faith in its social dimension.

Since for the relations with newcomers, that is, with immigrants, to translate into a new, higher and better quality - spiritual, material, cultural, it takes first of all a living and strong faith. Why? It should be noted that a person who decides to migrate leaves his home and sets off into the world with a strong faith that he will find a new and better future for himself elsewhere. Therefore, faith is the strength that gives rise to the courage to "go away" from one place and "arrive" at the new one, hitherto unknown. If faith has been a starting force for a migrant, then also the faith of those who receive it seems to be only a valuable "tool" for his later integration into the new environment. Only the strong faith of the host, his healthy system of spiritual values, etc., can become a tool to help the integration of the newcomers.

It is important that the various levels of government promote the integration process, but the most important thing, I believe, is a strong faith in God and fidelity to the spiritual values that it derives from. In fact, when the faith of those who receive immigrants is weak, or when it is not expressed in life by the values that derive from it, they can easily be culturally dominated by immigrants. Their faith, their system of values and their beliefs, which motivated them to embark on a journey in the hope of finding a place for their "better" future, can be spiritually stronger and "take control" over the culture of the hosts. It must be remembered that at the starting point an immigrant owes a lot to his faith. He asks God for a blessing and thanks Him when he receives it. He also feels obliged to be thankful for the future, when it turns out to be opportune to him. He takes "His" God with him when he goes on the way.

When there is no strong faith in God on the part of the hosts, full integration will never happen. At most, there will be economic or political integration, but not spiritual or cultural integration. Slowly, but very systematically, the identity of the host country will be disintegrated and the identity of the newcomers will take over. History knows many such cases. One of them is Christianity itself, which has slowly replaced the beliefs of the Romans, imposing a new Christian identity on the whole Roman empire.

State institutions must seek integration on a legal, economic, and social level, but it is up to the believers to (ecumenically) incorporate the newcomers into the relationship with the God of Jesus Christ. He is the source of a certain ethical and moral system and gives meaning to suffering and death. Because migration causes a kind of "mixing" of people, their beliefs, cultures, spiritual needs, the task of integration is to "sew together" the torn fabric of social, spiritual, cultural life. The ecumenical 
movement must therefore provide the spiritual and theological tools that are essential for deepening and accelerating integration. It can also make it last.

Ecumenism lives with the conviction that man and woman cannot be a constant "migrants," cannot live in a constant ghetto. Man needs unity, a certain domestication (oikos), the possibility of entering into good relations with others, including those whom he has not yet met or whose existence he thus far ignored. This longing for a "shared home" 20 teaches that man needs a certain stability and steadiness for his full development. But it is not only about physical or material stability. Nor does the ecumenical movement aim to stop migration, but above all to work out and adopt as much as possible this ethical system, a certain hierarchy of values, a clearly defined spiritual area, common concepts and goals that only God can give.

Is the modern ecumenical movement able to deliver this? One gets the impression that the current ecumenical movement has become a bit too horizontal and less vertical. It is perceived to have fewer clear references to God. It counts less on His support and on His grace, and more on the action of people as hope for a better future. Also, in ecumenical dialogues, issues of a theological or dogmatic nature are less often addressed, and more willingly focus on social, economic, or educational issues. Of course, human actions are important, even indispensable in the process of full integration, but they are not a source of lasting integration. They are an additional, motivating and periodic force. Human activities only seemingly create unity, but in reality they accept the existence of belief and religious ghettos. Full integration requires Christians to share their faith in Jesus Christ, Lord and Saviour.

Full integration is called individual or collective identity. ${ }^{21}$ Since migration violates - to a greater or lesser extent - the individual or collective identity, both of the country that receives immigrants and of the immigrants themselves, integration aims to rebuild it, but no longer in the mental structures, but enriched with new impulses that are the contribution of immigrants. The basis/foundation - in our context it is about faith in the God of Jesus Christ - remains unchanged, but the superstructure is being changed.

${ }^{20}$ This is how the sense of the ecumenical movement can be interpreted as a longing for a 'shared home."

${ }^{21}$ I have had the opportunity to write about identity before, see Z. J. KiJAs: “O tożsamości, wierze i przyjaźni." In: Wschód i Zachód. Miejsca spotkań. Eds. A. Świerzowska, K. Skowronek, in cooperation with Z. Pasek. Kraków 2018, pp. 21-30. 


\section{Bibliography}

Bugdol M.: Wartości organizacyjne: szkice z teorii organizacji $i$ zarzadzania. Kraków 2006.

JoHN XXIII: Encyclical Letter "Mater et Magistra” [15.05.1961].

JoHN XXIII: Encyclical Letter "Pacem in Terris" [11.04.1963].

John PAul II: Encyclical Letter “Laborem Exercens" [14.09.1981].

John PAul II: Message for the 88 th World Day of Migration 2002: “Migration and Inter-Religious Dialogue" [25.07.2001]. http://www.vatican.va/content/johnpaul-ii/en/messages/migration/documents/hf_jp-ii_mes_20011018_worldmigration-day-2002.html [access 30.06.2020].

Glaeser Z.: “'Swój’ i 'obcy’ w perspektywie doktryny chrześcijańskiej.” In: „Swój” i „obcy” $w$ kontekście współczesnego kryzysu migracyjnego. Doświadczenia i zadania Kościołów i społeczeństwa. Eds. Z. Glaeser, G. Giemza. Warszawa 2017, pp. 17-31.

GozI S.: "Kilka refleksji na temat: 'Imigracja i integracja'." In: Migracja — wyzwanie XXI wieku. Ed. M. S. ZIĘBA. Lublin 2008, pp. 121-126.

Kijas Z. J.: Odpowiedzi na 101 pytań o ekumenizm. Kraków 2004.

Kijas Z. J.: “O tożsamości, wierze i przyjaźni.” In: Wschód i Zachód. Miejsca spotkań. Eds. A. ŚwierzowsKa, K. SKowroneK, współudział Z. Pasek. Kraków 2018, pp. 21-30.

Paul VI: Apostolic Letter in the Form of Motu Proprio "Pastoralis Migratorum Cura” [15.08.1969].

Paul VI: Apostolic Letter “Octogesima Adveniens” [14.05.1971].

Pontifical Council for the Pastoral Care of Migrants and Itinerant People: Instruction Erga Migrantes Caritas Christi (The Love of Christ Towards Migrants) [3.05.2004]. http://www.vatican.va/roman_curia/pontifical_ councils/migrants/documents/rc_pc_migrants_doc_20040514_ergamigrantes-caritas-christi_en.html [access 30.06. 2020].

Rządowa Rada Ludnościowa: Sytuacja demograficzna Polski. Raport 20102011. Warszawa 2011.

Vatican Council II: Decree on Ecumenism "Unitatis redintegratio" [21.11.1964].

Wokół problematyki migracyjnej. Kultura przyjęcia. Eds. J. BALICKI, M. ChamaRczUK, Warszawa 2013. 
ZDZISŁAW J. KIJAS

\title{
Migrazione - ecumenismo - integrazione
}

\begin{abstract}
I tre concetti: migrazione, ecumenismo e integrazione sono ricchi di significato. Il loro ordine e la gerarchia sono importanti. La migrazione è più o meno la libera circolazione delle persone, dei singoli o di interi gruppi. L'ecumenismo, a sua volta, è un appello e un'azione. La sua missione/compito è la necessità di riconoscere persone che rappresentano un'altra religione e di fare tentativi/sforzi per integrarle in un insieme con persone che credono in modo un po' diverso, ma nello stesso Dio. L'integrazione è ripristinare o costruire un insieme integrale con persone che vivono in un dato territorio. La piena integrazione si chiama identità - individuale o collettiva. Poiché la migrazione disturba - in misura maggiore o minore - l'identità individuale o collettiva sia del Paese che accoglie gli emigrati che quella degli stessi immigrati, l'integrazione mira quindi a ricostruirla, ma non nelle strutture mentali esistenti, ma arricchita di nuovi impulsi che sono contributo degli immigrati. Il fondamento/la base - nel nostro contesto, si tratta della fede nel Dio di Gesù Cristo - rimane invariato, mentre cambia la sovrastruttura.
\end{abstract}

Parole chiave: migrazione, ecumenismo, integrazione, fede, pellegrinaggio, libertà, Chiesa

ZDZISŁAW J. KIJAS

\section{Migration — œcuménisme - intégration}

\section{Résumé}

Les trois concepts de migration, d'œcuménisme et d'intégration sont riches de sens. Leur ordre et leur hiérarchie sont importants. La migration est plus ou moins le déplacement plus ou moins libre de personnes, d'individus ou de groupes entiers. L'œcuménisme, quant à lui, est un appel et une action. Sa mission/tâche est la nécessité de représenter une minorité religieuse par rapport aux communautés existantes et de faire des tentatives/efforts pour les incorporer dans un même ensemble avec les personnes qui croient un peu différemment, mais au même Dieu. L'intégration consiste à restaurer ou à construire un tout intégral à partir des personnes vivant sur un territoire donné. L'intégration complète est appelée identité — individuelle ou collective. Puisque la migration perturbe plus ou moins l'identité individuelle ou collective du pays d'accueil et des immigrés eux-mêmes, l'intégration vise donc à la reconstruire, non pas dans les structures mentales existantes, mais dans une structure enrichie de nouvelles impulsions qui sont les contributions des immigrés. La base/le fondement - dans notre contexte, il s'agit de la foi dans le Dieu de Jésus-Christ - reste inchangée, tandis que la superstructure connaît un certain changement.

Mots clés : migration, œcuménisme, intégration, foi, pèlerinage, liberté, Église 